\title{
Role of Lung in the Pathogenesis of Rheumatoid Arthritis-A Commentary
}

\author{
*Neema Tiwari \\ Department of Pathology, Eras Lucknow University, India
}

Submission: August 27,2017; Published: August 29, 2017

*Corresponding author: Neema Tiwari, Department of Pathology, Eras Lucknow University, Uttar Pradesh, India, Email: nehaneemat@yahoo.co.in

\section{Commentary}

Many studies have identified strong associations between the lung and rheumatoid arthritis (RA), where they have seen a high prevalence of lung disease RA. It has been suggested that lung disease in RA results from targeting of the lung from circulating autoimmunity or other factors such as medications. However, findings that lung disease, specifically inflammatory airways disease, and lung generation of autoimmunity can be present before the onset of joint symptoms suggest that immune reactions in the lung may be involved in the initial development of RA-related autoimmunity.

The primary clinical manifestation of rheumatoid arthritis (RA) is joint disease, although RA-related injuries to other tissues, including the lung, have long been recognized in RA. This extra-articular tissue involvement has typically been thought of as being a target of RA-related autoimmunity, or an effect of medications or secondary infections. However, emerging data suggest that the lung may play a role in the initiation of RA, and not just be a target of autoimmunity or other processes, with this initiation perhaps due to gene and environmental interactions at the mucosal surface of the lung. Identification of elevations of circulating RA-related auto antibodies in absence of joint disease has proved that RA may be initiated outside of the joints and in the lung.

The airways may be a site of initiation of autoimmunity in RA, while the parenchyma may be a target of circulating autoimmunity that leads to nodules or interstitial lung disease (ILD). Novel methods to assess generation of autoimmunity at specific anatomic sites, including cellular and humoral responses, and systemic and local inflammation are under study. These methods will also likely need to include ways to safely obtain informative mucosal-based specimens. Also needed are new tools to investigate potential triggers for disease including advanced genetic and microbial analyses. Perhaps most importantly, novel cohorts are needed that can be used to evaluate the natural history and pathogenesis of RA, and offer new perspectives on how RA develops including a focus on the lung. Importantly, advances in understanding this area may lead to improved means of treating lung disease in patients with RA, as well as ultimately develop preventive strategies for RA that may target the lung.

\section{Your next submission with Juniper Publishers will reach you the below assets}

- Quality Editorial service

- Swift Peer Review

- Reprints availability

- E-prints Service

- Manuscript Podcast for convenient understanding

- Global attainment for your research

- Manuscript accessibility in different formats

( Pdf, E-pub, Full Text, Audio)

- Unceasing customer service

Track the below URL for one-step submission https://juniperpublishers.com/online-submission.php 